\title{
Cow Urine: A Boon for Sustainable Agriculture
}

\section{Sunita Choudhary ${ }^{1}$, Manish Kushwaha ${ }^{4}$, Seema $^{2} *$, Preeti Singh ${ }^{2}$, R. Sodani ${ }^{3}$ and Sunil Kumar ${ }^{1}$}

${ }^{1}$ Department of Agronomy, Banaras Hindu University, Varanasi- 221 005, Uttar Pradesh, India

${ }^{2}$ Soil Science and Agricultural Chemistry, Banaras Hindu University, Varanasi- 221005 , Uttar Pradesh, India

${ }^{3}$ Plant Physiology, Banaras Hindu University, Varanasi- 221 005, Uttar Pradesh, India

${ }^{4}$ Forage Research and Management Centre, NDRI, Karanal, Haryana - 132001, India

*Corresponding author

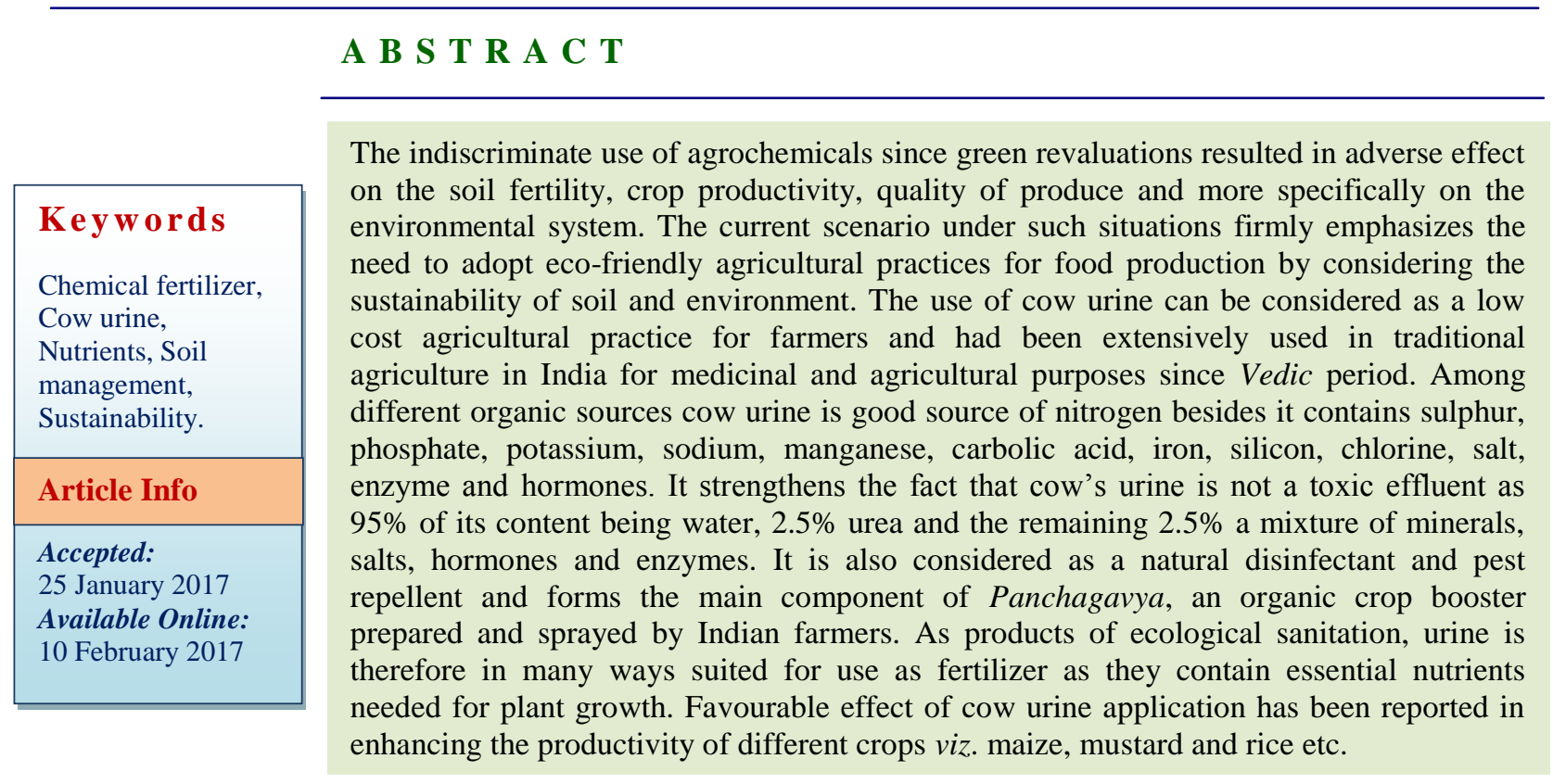

\section{Introduction}

India is primarily agrarian, and this sector provides livelihood to a major part of the population. To feed the 1.3 billion population of the country, increasing tremendously approximately at $1.2 \%$ every year, the food grain production need to be increased correspondingly, towards attaining this goal, there is requirement of higher doses of fertilizers, which require non-renewable energy. In the same time, declining factor productivity owing to imbalanced and indiscriminate use of fertilizers in most productive zone of the country i.e. Indo Gengatic Plains, food grain production in India reached to the plateau. Thus, the importance of organic sources of nutrients was recognized in current scenario in order to get higher yield without disturbing soil health 
(Arif et al., 2012a). In this context, integrated use of chemical and organic source of nutrients in crop production is becoming very crucial for assurance of food security on sustainable basis, which in turn not only improve the soil fertility for sustained crop productivity but also to reduce the cost of inorganic fertilizers. Different kind of organic materials such as FYM, animal manures, crop residues, composts, cow urine etc. have been used in crops but the amount and availability of nutrients in organic material vary widely, which makes interpretation of the value of nutrient supplied.

Livestock wealth is deemed as the oldest wealth resource for mankind. Cow represents the Vedic values of selfness service, strength, dignity and non-violence. The "Cow" occupies the highest place of honour in Indian civilization. The five products of cow (urine, dung, ghee, milk and curd) are used in different organic systems. Many farmers are reviewing age old practices of applying cow dung, cow urine, and their products in the form of manures and pesticides. The average size of land holding in India has declined to 1.32 ha in 2000-01 from 2.30 ha in 1970-71. If this trend continues the average size of land holding would be about 0.68 ha in 2020 and would be further reduced to 0.32 ha in 2030 (Anonymous, 2011). Majority of farmers in India are small farmers and about $70 \%$ of the population engaged in agriculture. Thus, with small holdings and small scale farming, there is no other better alternative than involving cattle in farming system.

The use of cow urine is known for a long time in India. Cow urine has been described as a liquid with innumerable therapeutic values, capable of curing several incurable diseases in human beings and plants. It has been considered that cow urine is very useful in agricultural operations as a bio fertilizer and bio pesticide (Dharma et al., 2005). It is rich source of macro, micronutrients and has disinfectant and prophylactic properties thus purify the atmosphere and improve soil fertility (Pathak and Ram, 2013). Cow urine therefore, could be an effective tool to address multi nutrient deficiencies in most of soils in the country. It is believed to provide nutrients to plants at low cost; therefore, it is considered an alternative for plant nutrition, metabolic activation and pest and disease control (PESAGRO-RIO, 2002). It is unfortunate that with the advent of fertilizers, slowly Indian farmers have forgotten use of cow products in agriculture and thus facing the current crises. Now it is high time that the farming community and scientific fraternity realize the importance of cow for assuring sustainability in farming and try to bring the glory of cow again with our culture and agriculture.

\section{Effect of cow urine on different aspects}

\section{Growth parameters}

Application of cow urine accelerates the different aspects of growth in several crops .e. maize, rice, mustard, lettuce (Devakumar et al., 2014; Pradhan et al., 2016; Oliveira et al., 2009; Qibtiyah et al., 2015, respectively). Seed priming with $\mathrm{P}, \mathrm{Zn}$, human and cow urine can potentially improve crop growth and yield of maize on low-fertility acid soils of northeast India (Kumar, 2014). Cow urine at 5 and $10 \%$ concentration significantly improved all vegetative parameters of gladiolus viz.- earlier $50 \%$ emergence of corms, increased emergence of plants, plant height, number of leaf, length and width of leaves (Tamaraker et al., 2016). Urine sources (human, cattle and got urine) had significantly taller maize plants as compared to control (Nwite et al., 2015). Increase in cow urine concentrations increased the performance of all phenotypic characters of methi and bhindi such as plant height, shoot and root length, 
number of leaf, leaf length and breadth were increased with increased concentration of urine as compared to control (Jandaik et al., 2015). Application to soil at $20 \mathrm{ml} /$ plant of cow urine solution at the concentration of $0.86 \%$ provided $10 \%$ increase in fresh matter of lettuce cv. Romana, in comparison to the control (Gadelha et al., 2003). Among the 6 ratios of water to urine $(10: 1,8: 1,6: 1,4: 1$, $2: 1$, and 1:1), higher plant height $(279.42 \mathrm{~cm})$ was observed with 6:1 ratio (Ayalew, 2015).

\section{Yield and yield attributes}

The yield and yield characters get affected significantly in crops exposed to cow urine viz.- maize, rice, mustard, gladiolus, broccoli etc. (Devakumar et al., 2014 and Veeresha et al., 2014; Qibtiyah et al., 2015, Tamaraker et al., 2016 and Sharma et al., 2016, respectively). PSB + cow urine application recorded higher values of grain yield and biological yield than PSB + Azospirilum (Abraham and Lal, 2004). Application of cow urine up to 900 1/ha as basal dose markedly improved yield attributes as well as seed and stover yield of mustard (Pradhan et al., 2016). There was significantly higher maize grain yield was found in different urine sources (human, cattle and got urine) of urine treated pots as compared to control (Nwite et al., 2015). Application of $\mathrm{N}$ at $125 \mathrm{~kg} / \mathrm{ha}$ and 100 $\mathrm{kg} / \mathrm{ha}$ by urine recorded highest biological yield (53.71 t/ha) and curd yield (20.08 t/ha) of cauliflower, respectively (Khanal et al., 2010). Highest total fresh amaranth biomass was obtained from cattle urine fortified organic fertilizer (Adeoluwa et al., 2009). Urine-biochar treatment led to a pumpkin yield of $82.6 \mathrm{t} / \mathrm{ha}$, which was $85 \%$ increase compared with the biochar-only treatment (Schmidt et al., 2015). Six foliar sprays of $55 \%$ cattle urine solution resulted highest fruit weight, volume, number of fruit, fruit yield $\mathrm{kg} / \mathrm{plant}$ and yield tons/ha of mango compared to control (Damodhar et al., 2010).
Maximum fruit weight, length and volume of mango fruits was recorded in $30 \%$ cattle urine foliar sprays at pea stage + marble stage + egg stage (Jadhav, 2007). Water to urine mix of 8$6: 1$ among the ratios of $10: 1,8: 1,6: 1,4: 1$, $2: 1$, and $1: 1$ has a great blow to maximize productivity of maize grain yield up to 104.94 q/ha (Ayalew, 2015). Application of recommended dose of nitrogen through human urine in three split doses plus gypsum recorded higher yield for ashgourd, french bean, pole bean and pumpkin, and it was at par with recommended dose of nitrogen through cattle urine in three splits plus gypsum and recommended dose of fertilizers (Yogeeshappa et al., 2016).

\section{Plant nutrient content}

Protein content and chlorophyll content of methi and bhindi were increased with increased concentration of urine as compared to control (Jandaik et al., 2015). Urine increased the $\mathrm{N}$ concentration of grass and increased the potassium concentration of grass and clover (Ledgard et al., 1982).

\section{Soil physical and chemical properties}

Significantly high soil organic carbon (0.58\%), available nitrogen (272.4 kg/ha), phosphorus (23.5 kg/ha) and potassium (199.9 $\mathrm{kg} / \mathrm{ha}$ ) were obtained with the application of FYM $12.5 \mathrm{t} / \mathrm{ha+cattle}$ urine at $34300 \mathrm{l} / \mathrm{ha}$ as compared to control (Veeresha et al., 2014). Higher total nitrogen, available phosphorus, $\mathrm{Ca}, \mathrm{Mg}$, organic carbon, $\mathrm{pH}$, exchangeable $\mathrm{K}$ and $\mathrm{Na}$ were obtained under human and cattle urine treatments as compared to control (Nwite et al., 2015). High dose of LCM (Liquid Cow Manure) application resulted in increased $\mathrm{pH}$ and $\mathrm{EC}$ values, nutrients and DOC (Dissolved Organic Carbon) content of amended soils (Aguilera et al., 2010). Nitrogen at $150 \mathrm{~kg} / \mathrm{ha}$ by urine through foliar application gave the highest soil $\mathrm{pH}$ (6.1), 
organic matter (5.43\%), phosphorus (147 $\mathrm{kg} / \mathrm{ha}$ ) and the nitrogen $(0.31 \%)$ which was significantly higher than $\mathrm{N} 0$ whereas $\mathrm{N}$ at 50 $\mathrm{kg} / \mathrm{ha}$ gave the highest potassium $(242 \mathrm{~kg} / \mathrm{ha})$ which was significantly higher than the lowest $187 \mathrm{~kg} / \mathrm{ha}$ from N0 (Sharma et al., 2016).

\section{Soil microbial population}

Significantly higher soil microbial population viz., bacteria $(47.0 \times 105 \mathrm{cfu} / \mathrm{g})$, fungi $(34.6 \times 104 \mathrm{cfu} / \mathrm{g})$ and actinomycetes $(40.0 \times 103 \mathrm{cfu} / \mathrm{g})$ were obtained with the application of FYM $12.5 \mathrm{t} / \mathrm{ha}+$ cattle urine at 34300 1/ha as compared to control (Veeresha et al., 2014). Compost tea (cow dung+cow urine+water) containing high amounts of microbes was found to have complemented the activity of the native microbes and favoured decomposition of organic matter at a faster rate resulting in better transformation of nutrients and their availability to crops (Pathak and Ram, 2002). Urine caused an increase in soil respiration of $>50 \%$ and the average increase were greater for cow's urine (30.8 $\mathrm{mg} \mathrm{CO} 2 / \mathrm{m}^{2} / \mathrm{min}$ ) than for artificial urine (20.1 $\mathrm{mg} \mathrm{CO} \mathrm{CO}_{2} / \mathrm{m}^{2 /} \mathrm{min}$ ) (Lovell and Jarvis, 1996). Incorporation of increasing dose of LCM (liquid cow manure) resulted in increased respiration activity, $\mathrm{C}-\mathrm{CO}_{2}$ evolution and soil enzymatic activities of amended soils (Aguilera et al., 2010).

\section{Post-harvest parameters}

Cow urine at 5 and $10 \%$ concentration significantly improved all post harvest parameters of gladiolus viz.- percent opened flower in vase, diameter of basal floret, shelf life and vase life of cut spikes as compared to control (Tamaraker et al., 2016). Maximum reduction in strychnine and brucine contents was found when the seeds of Nux vomica (Kupeelu) were purified by keeping them in cow's urine for seven days followed by boiling in cow's milk for $3 \mathrm{hrs}$, out of these three methods (by using cow's urine and cow's milk as media alone and together ) (Mitra et al., 2012).

In conclusion, increasing prices of chemical fertilizer and non-effient role in long term to sustainable production, there is a need of application of organic source of nutrients including cowdung for enhancing maximum productivity in sustainable way with better soil health. It is a effctive tools to improves physico-chemical and biological properties of the soil with higher yield of plants in sustained basis without deleting the fertility of soil Lets, hope the use of cow urine could open the door of sustainable agricultural production because as known it is ecofriendly, economically viable, and easily available at abundance.

\section{References}

Annonymous. 2011. ICAR, Vision 2030, pp. 2-3.

Arif, M., Ali, A., Umair, M., Munsif, F., Ali, K., Inamullah, M., Saleem and Ayub, G. 2012a. Effect of biochar, FYM and mineral nitrogen alone and in combination on yield and yield components of maize. Sarhad J. Agri., 28(2): 191-195.

Ayalew, M. 2015. Cattle urine technology to maximize maize grain yield: Cattle urine technology to maximize maize grain yield applicable to small holder farmers by evaluating maize grain yield; Gondar, North West Ethiopia. Integrated J. British, 2(2): 79-91.

Bhadauria, H. 2002. Cow Urine- A Magical Therapy. Vishwa Ayurveda Parishad. Int. J. Cow Sci., 1: 32-36.

Damodhar, V.P. and Shinde, V.V. 2010. Effect of cattle urine sprays on yield and quality of mango (Mangifera indica L.) cv. Alphonso. The Asian J. 
Horticulture, 5(2): 307-308.

Devakumar, N., Shubha, S., Rao, G.G.E. and Imrankhan. 2014. Studies on soil fertility, cow urine and panchagavya levels on growth and yield of maize. Proceedings of the $4^{\text {th }}$ ISOFAR Scientific Conference. 'Building Organic Bridges', at the Organic World Congress 2014, 13-15 Oct., Istanbul, Turkey.

Gadelha R.S.S., Celestino, R.C.A., Shimoya, A. 2003. Efeito da utilização de urina de vaca na produção da alface. Pesquisa Agropecuária \& Desenvolvimento Sustentável, 1: 179-182.

Jandaik, S., Thakur, P. and Kumar, V. 2015. Efficacy of cow urine as plant growth enhancer and antifungal agent. $A d v$. Agri., Volume 2015, Article ID 620368, 7 pages.

Khanal, A. 2010. Effects of cattle urine, urea and their combinations on yield and quality of cauliflower (Brassica oleracea var. botrytis L.) M.Sc. Thesis, Department of horticulture, Institute of Agriculture and Animal Science, Rampur, Chitwan, Nepal.

Kumar, M. 2014. Influence of seed priming with urine, phosphorus and zinc on maize (Zea mays L.) yield in an acid soil of Northeast India. Indian J. Hill Farming, 27(1): 132-137.

Lovell, R.D. and Jarvis, S.C. 1996. Effects of urine on soil microbial biomass, methanogenesis, nitrification and denitrification in grassland soils. Plant and Soil, 186: 265-273.

Mitra, S., Shukla, V.J., Acharya, R. 2012. Effect of purificatory measures through cow's urine and milk on strychnine and brucine content of kupeelu (Strychnos nuxvomica linn.) seeds. African J. Traditional Complementary Alternative Med., 9(1): 105-111.

Nwite, J.N. 2015. Effect of different urine sources on soil chemical properties and maize yield in Abakaliki, Southeastern Nigeria. Int. J. Adv. Agricultural Res., 3: 31-36.

Oliveira, N.L.C., Puiatti, M., Santos, R.H.S., Cecon, P.R., Rodrigues, P.H.R. 2009. Soil and leaf fertilization of lettuce crop with cow urine. Horticultura Brasileira, 27: 431-437.

Pathak, R.K. and Ram, R.A. 2002. Approaches for organic production of vegetable in India. In Report of Central Institute of Sub-Tropical Horticulture, Lucknow, India, p: 73.

Pathak, R.K. and Ram, R.A. 2013. Bioenhancers: A potential tool to improve soil fertility, plant health in organic production of horticultural crops. Progressive Horticulture, 45(2): 237 254.

PESAGRO-RIO. 2002. Urina de vaca: alternative efiiente e barata. (Documentos, n. 96). 8 p.

Pradhan, S., Bohra, J.S., Bahadur, S., Rajani and Ram, L. 2016. Effect of fertility levels and cow urine application on the performance of Indian mustard [Brassica juncea (L.) Czernj. \& Cosson]. J. Pure and Appl. Microbiol., 10(2): p1637.

Qibtiyah, M., Aini, N., Soelistyono, R. 2015. The effect of application time and dosage of biourine on growth and production of rice (Oryza sativa L.). J. Agri. Vet. Sci., 8(1): 26-30.

Saunders, W.H.M. 1982. Effect of cow urine and its major constituents on pasture properties. New Zealand J. Agri. Res. 25(1): 61-68.

Schmidt, H.P., Pandit, B.H., Martinsen, V., Cornelissen, G., Conte, P., Kammann, C.I. 2015. Fourfold increase in pumpkin yield in response to low-dosage root zone application of urine-enhanced biochar to a fertile tropical soil. Agri., 5: 723-741.

Sharma, Shah, S.C., Adhikari, K.R., Shah, P. 
and Shrestha, J. 2016. Effects of cattle urine and FYM on yield of broccoli and soil properties. J. Agri. Search, 3(3): 157-160.

Singh, M.K., Singh, R.P., Rai, S. 2014. Effect of nitrogen levels and cow urine on soil $\mathrm{N}$ status, growth and yield on paddy (Oryza sativa L.). Environ. Ecol., 32(4): 1277-1281.

Tamarkar, S.K. 2016. Effect of plant growth regulators, vermivash and cow urine on vegetative growth, flowering, corm production and vase life of gladiolus var. Candyman. Ph. D. thesis, Department of horticulture, college of agriculture, Indira Gandhi Krishi Vishwavidyalaya, Raipur (Chhattisgarh).

Veeresha, Sharanappa, Gopakkali, P. 2014. Effect of organic production practices on yield and soil health of irrigated maize (Zea mays L.) as influenced by various levels of FYM and cattle urine application. Environ. Ecol., 32(2A): 627-630.

Yogeeshappa, H. 2012. Studies on the effect of repeated application of human and cattle urine on soil properties, growth and yield of vegetable crops. Ph.D. Thesis, Department of soil science and agricultural chemistry, University of Agricultural Sciences, Bengaluru.

Yogeeshappa, H., Srinivasamurthy, C.A., Krishnamurthy, D. 2016. Effect of repeated application of human urine and cattle urine on soil properties and yield of vegetable crops. Asian J. Soil Sci., 11(1): 29-36.

\section{How to cite this article:}

Sunita Choudhary, Manish Kushwaha, Seema, Preeti Singh, Sodani, R. and Sunil Kumar. 2017. Cow Urine: A Boon for Sustainable Agriculture. Int.J.Curr.Microbiol.App.Sci. 6(2): 18241829. doi: http://dx.doi.org/10.20546/ijcmas.2017.602.205 